\title{
Dynamic coordination mechanism of paste strength and roof load for gob-side entry retaining
}

\author{
Nong Zhang China University of Mining and Technology, China \\ Changliang Han China University of Mining and Technology, China \\ Ke Yang China University of Mining and Technology, China
}

\begin{abstract}
After filling, paste reaches its heyday with the paste wall capable of repeatedly withstanding the fracture pressure of goaf roof. The strength of paste wall should be no less than the roof weighting. In order to identify the dynamic coordination mechanism of filling wall strength and roof pressure, the movement principle of goaf roofs was studied in detail. The weighting characteristics of roofs at different stages were differentiated, with the weighting pressure of specific roof strata structure also obtained. Requirements for the mechanical properties of paste filling wall at different stages of its strength-developing period was also proposed. Paste materials that meet the dynamic coordination requirements were formed based on the experiments for aggregate size and ingredients ratio and consist of crushed stone, sand, cement, coal ash, additive and water. An industrial test was carried out, and the actual effect of paste wall proves the rationality of research results.
\end{abstract}

\section{Introduction}

The technology of gob-side entry retained for next sublevel have various advantages over traditional ones, such as the reducing of roadway drivage rate (Tan et al., 2015; Zhang et al., 2012), the improvement of the coal recovery rate (Li et al., 2016; Sun et al., 2014) and the simultaneous exploitation of coal and gas. With filling and retaining being the mainstream method (Han et al., 2013; Hua and Li, 2016), the filling quality is one of the most important factors (Ning et al., 2013; Han et al., 2015). The filling pump transports filling materials to moulds at the edge of gob to support the gob roof and keep the god airtight after consolidation. The filling materials generally include solid materials (Wang et al., 2016; Han et al., 2013), high water materials (Wang and Zhang, 2016) and paste concrete materials (Zhang et al., 2003). Among them, paste materials are widely used because of their adjustable solidification time, controlled process strength and high bearing pressure strength.

Figure 1 is the schematic diagram of paste filling for gob-side entry retaining. Filling moulds are set along the gob edge at the rear of the working face. The filling pump is arranged in front of the working face and could pump as deep as $500 \mathrm{~m}$, which reduces the amount of times the pump moves. When a mould is full and the paste material solidifies, it can be detached and moved to the next filling area. 


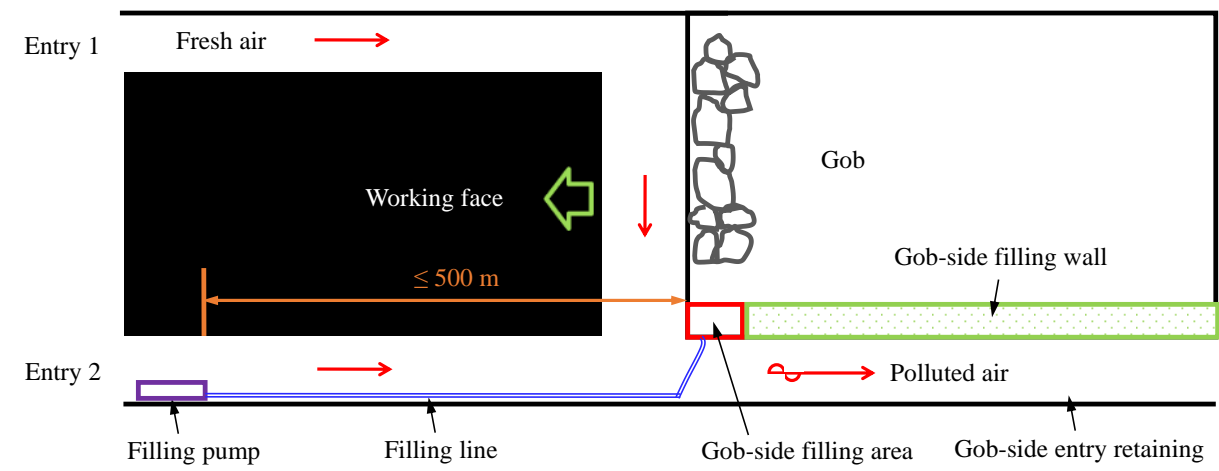

Figure 1 Schematic diagram of paste filling for gob-side entry retaining

The required strength of paste is reached within a certain period and weakens after filling. During this period, a paste wall needs to repeatedly bear the increasing load from the goaf roof fracture, and the strength of paste wall should be greater than the roof weighting. Dynamic mechanism coordination between filling wall strength and roof pressure should be achieved to prevent the paste wall from damage during the entire period.

Much research has been done in terms of the deformation characteristics and support technology of deep rock (Kang et al., 2010), the support adaptive principle and method of the god-side entry retaining (Tan et al., 2016), and the subsidence damage and control of surrounding rock structure in deep large mining height (Xie et al., 2015) YA combined filling body of gob-side entry retaining in over 1000 deep mines has also been proposed (Ye et al., 2016). However, the research on the dynamic coordination of filling body and roof load is still far from being enough and in this paper, topics of roof pressure characteristics, load-bearing characteristics of paste and the coordination mechanism are to be discussed.

\section{$2 \quad$ Characteristics of roof weighting on gob-side entry retaining}

\subsection{The fracture form of goaf roof}

The first fracture of the goaf roof is an "O-X" crack, and the later fractures resemble half of the "O-X" crack (see Figure 2). When fracture happens, arc triangles form (shade (1) in Figure 2) in each of the two god-side areas. The arc triangle is located directly above the retained entry, whose rotation and subsidence seriously affect the god-side entry retaining. From the most unfavourable point of view, the longest arc triangle strip is selected to analyse the movement of the roof.

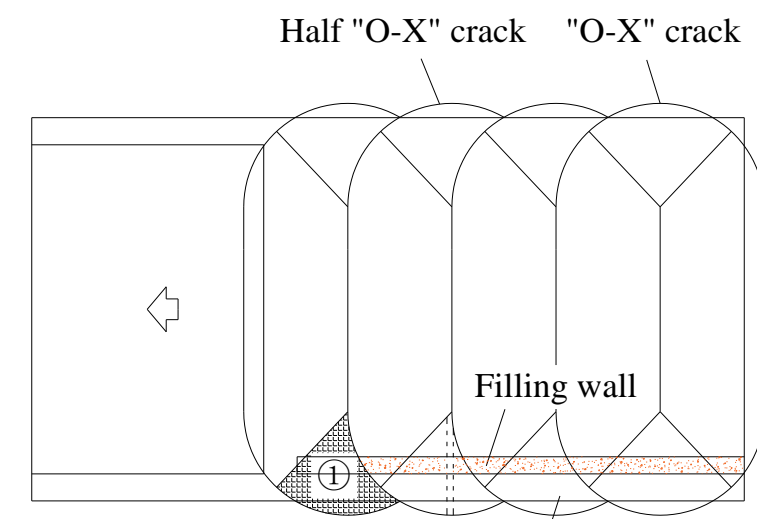

Gob-side entry retaining

Figure 2 Break configurations of roof over a gob 


\subsection{Movement of roof in gob-side entry retaining}

The movement of gob-side entry roof is shown in Figure 3.

After mining begins, both the immediate roof and the main roof are bent to sink (Figure 3(a)). The minor deflection of roof above the wall leads to a low wall pressure and slow growth rate. The scope of this movement is generally less than $0 \sim 5 \mathrm{~m}$.

When the mining length reaches a certain extent, the immediate roof starts to break (Figure 3(b)) and is scattered on the gob floor, losing contact with the lateral strata. Therefore, the collapsed immediate roof has no impact on the wall load. However, after the loss of restraint, the remaining immediate roof will suffer from lateral deformation, which absorbs some of the subsidence of the main roof and reduces the growth rate of wall load.

With the increase of mining distance, the suspension distance of the main roof increases to a certain extent, breaking the main roof and forming two blocks of $A$ and $B$ (Figure $3(c)$ ) which rotate and sink along the side of the fracture. This period witnesses the most rapid increase of wall load.

The main roof experience two breaks during the sinkage with rotation, forming three key blocks of $A, B$, and $C$ (Figure 3(d)). With these three blocks hinged with each other to form a stable structure, the wall load then grows slowly due to the gangue compaction and the further sinking of the main roof.

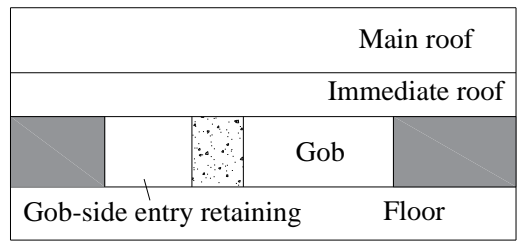

(a) Beginning of mining

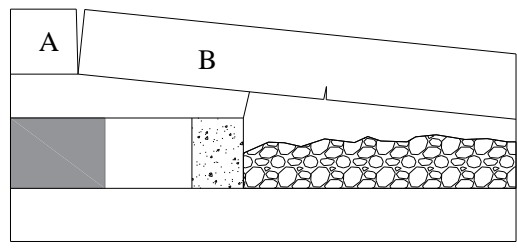

(c) Main roof crack

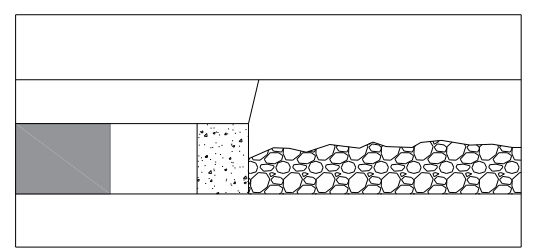

(b) Immediate roof crack

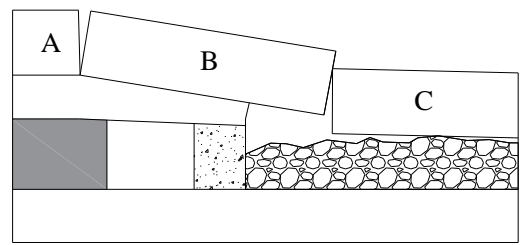

(d) Final structure

\section{Figure 3 Process of roofs movement}

\section{$3 \quad$ Bearing properties of paste filling body}

\subsection{Determination of filling wall load}

It can be seen that in the subsidence, fracture, rotation and stabilization of the roof, the wall load besides the entry is increasing. The bearing capacity of the wall beside the roadway can be calculated by the main roof subsidence above. The mechanical model is shown in Figure $4 . \mathrm{H}_{0}, \mathrm{~m}$, and $\mathrm{H}_{1}$ represent the thickness of the direct bottom, seam and the immediate roof respectively. L, $\theta$ and s represent the length, subsidence and rotation angle of $B$ block respectively. $s$ represents the subsidence of the main roof above lateral wall side. $x_{0}$ represents the horizontal distance between the main roof fracture point and the entry. $a$ and $b$ respectively represent the width of the retained entry and the roadside wall. 


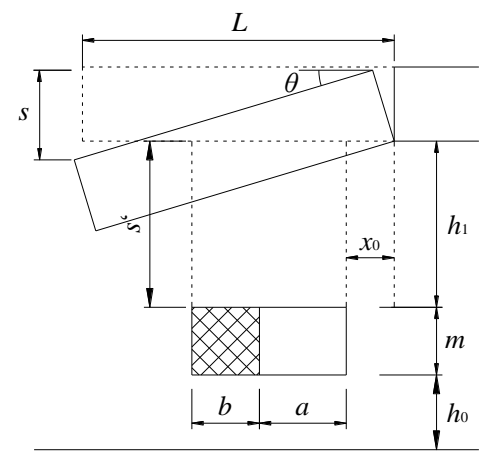

\section{Figure 4 Mechanical model}

According to the mechanical model, the sinkage of the main roof beside of the wall can be obtained:

$$
\mathrm{s}^{\prime}=\left(x_{0}+a+\mathrm{b}\right) s / L
$$

The subsidence of this point is beared directly by the immediate roof and the wall, with the extra load $\sigma$ caused by the deformation expressed as:

$$
\sigma=E_{0} \frac{s_{0}}{h_{0}}=E \frac{\Delta s}{m}=E_{1} \frac{s_{1}}{h_{1}}
$$

Combining Equation (1) and (2)

$$
\sigma=\frac{\left(x_{0}+a+\mathrm{b}\right) s}{L\left(\frac{h_{0}}{E_{0}}+\frac{m}{E}+\frac{h_{1}}{E_{1}}\right)}
$$

The final subsidence of the main roof:

$$
\mathrm{s}=\mathrm{m}-(\mathrm{K}-1) h_{1}
$$

In the formula, $K$ is the bulking coefficient of the immediate roof. Combining Equation (3) and (4), the maximum load required for filling wall can be obtained.

\subsection{Strength development of filling wall}

CHCT paste materials (Figure 5(a)) were formed after experiments for aggregate size and ingredients ratio and consist of crushed stone, sand, cement, coal ash, additive and water. The maximum strength of the materials can reach up to 7, 12, 16 and $28 \mathrm{MPa}$ respectively in 1, 3, 7 and $28 \mathrm{~d}$. The strength development is shown in Figure 5(b).

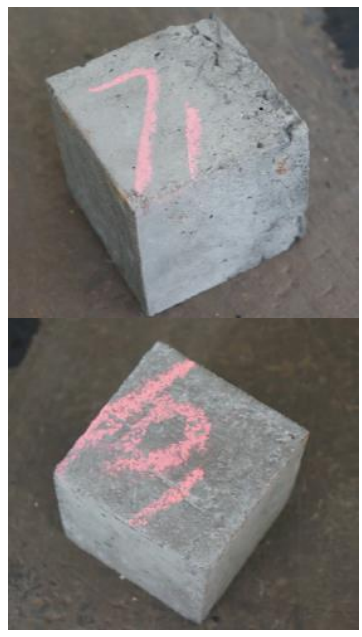

(a) Samples

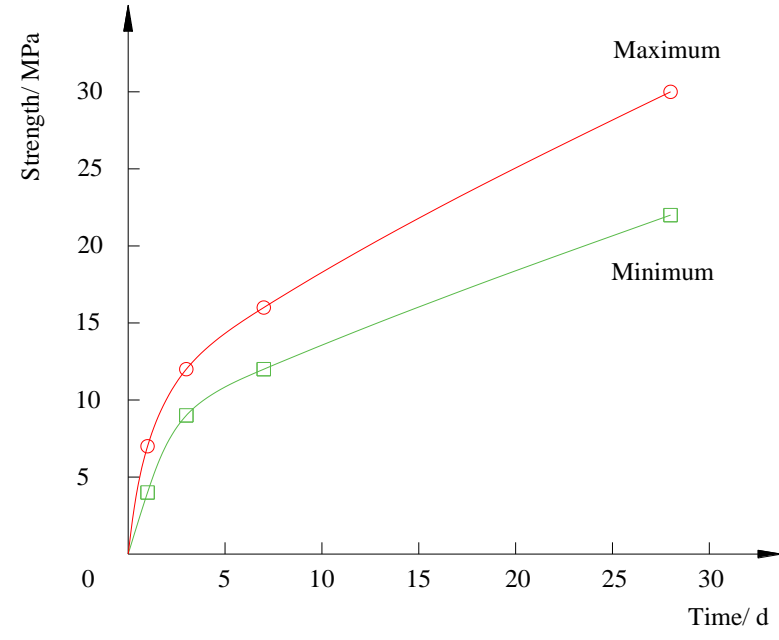

(b) Strength developing curves

Figure 5 Samples and strength of CHCT paste 


\section{Coordination mechanism of paste strength and roof load}

Given the dynamic development of paste strength and roof load, in order to ensure the structural stability of the retained entry, the paste strength should be larger than the roof load at every stage:

$$
\sigma_{p i} \geq \sigma_{i}
$$

According to statistics (Han, 2013), the sinkage prior to, during and after the collapse of the main roof is 15, 55 and 30\% respectively. According to Equation (3), the roof load can be obtained at all stages. The (mis) match of the two can be determined by combining the characteristics of paste strength development. If mismatch occurs, subsequent technical measures should be taken during mining:

(1) Support the roof of the edge of paste wall with strong single props to relieve the pressure of the roof.

(2) Presplit the roof to relieve its load the working face ahead, and to change roof fracture location and fracture (crack) structure.

\section{$5 \quad$ Industrial test}

\subsection{Basic conditions}

The average depth of coal seam in an E1403 working face is approximately $405 \mathrm{~m}$. The thickness of coal is 1.9 $\mathrm{m}$, and the dip angle is 3 degrees. The direct bottom is a layer of siltstone with a thickness of $3.4 \mathrm{~m}$. The immediate roof is $1.45 \mathrm{~m}$ thick siltstone and the main roof is $4.7 \mathrm{~m}$ thick fine sandstone. The width and height of the gob-side retained entry is 5.0 and $3.3 \mathrm{~m}$ respectively. The width of the wall beside roadway is $2.2 \mathrm{~m}$ and the average mining and recovery rate is $5 \mathrm{~m} / \mathrm{d}$.

The horizontal distance between the lateral fracture line of the main roof and the coal side of retained entry is $2 \mathrm{~m}$. The length of lateral hanging roof $L$ is $24.93 \mathrm{~m}$. The elastic modulus of the wall is $150 \mathrm{MPa}$. The elastic modulus of the immediate roof and the direct bottom is $120 \mathrm{MPa}$. The bulking coefficient the immediate roof $\mathrm{K}$ is 1.35 .

\subsection{Analysis of coordination between wall strength and roof load}

According to Equation (4), the maximum subsidence of the main roof is $1.39 \mathrm{~m}$. Combining Equation (3) and relevant parameters, the curve of the roof load with subsidence and time can be obtained (see Figure 6). The roof load increases linearly with the increase of subsidence until it reaches the maximum load of $12.51 \mathrm{MPa}$. In fact, it is not a uniform subsidence but one that is accelerating. Therefore, the growth process of roof load is nonlinear.

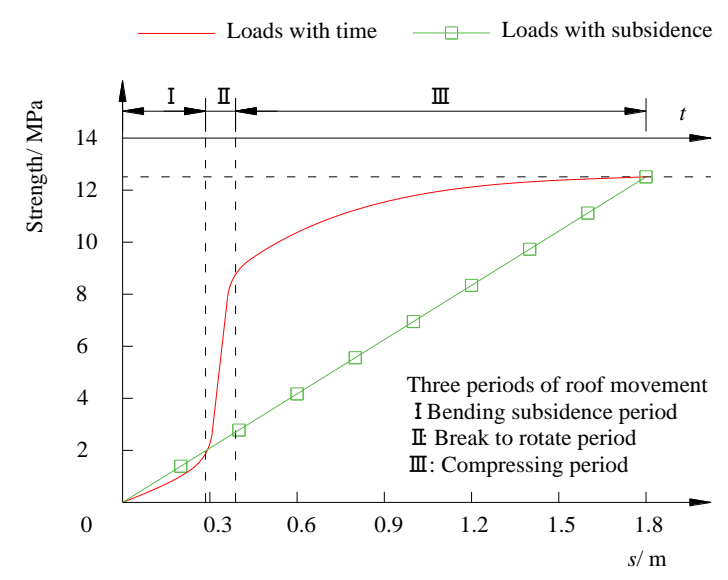

Figure 6 Loads of roof with time and subsidence 
The roadside wall strength must be greater than the roof load at any stage to ensure its stability. The shaded part in Figure 7 is the numerical range of the roof load for the stability of the wall. The roof load prior to, during and after collapse are $1.88,8.76$ and $12.51 \mathrm{MPa}$ respectively, less than the minimum strength of the wall, hence ensuring its stability.

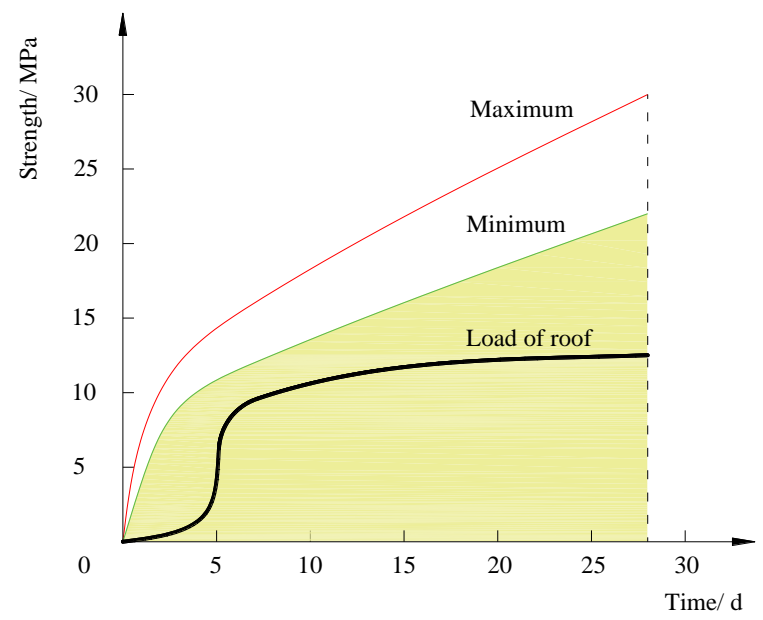

Figure 7 Coordination of roofs' load and paste wall's strength

\subsection{Gob-side entry effects}

During the experiment, the deformations of the surrounding rock and the bearing capacity of the wall were monitored. The final deformation of the gob-side retained entry features a width of $284 \mathrm{~mm}$ and a height of $449 \mathrm{~mm}$. The deformation control effect was favourable, and the entry section met the engineering demand. During mining, the paste wall beside the roadway stayed intact, and the bearing state was fine (Figure 8), thus verifying the rationality of the experiment results.

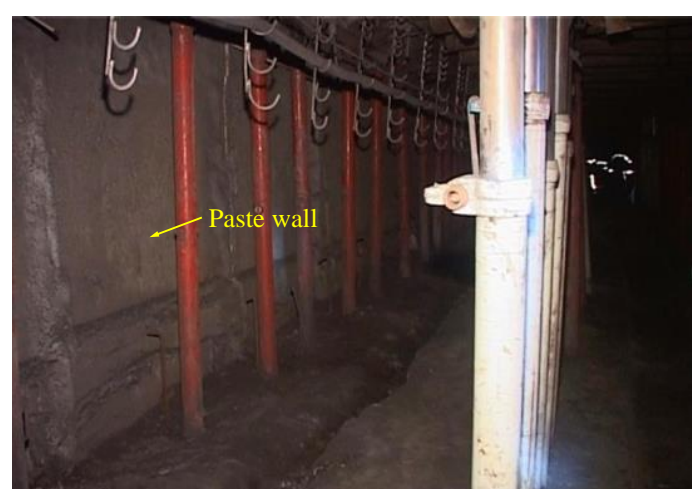

Figure 8 Actual effect of paste wall

\section{$6 \quad$ Conclusions}

The "O-X" crack and the half "O-X" crack successively occur in the gob roof, with the lateral arc triangles exerting the greatest influence on the gob-side entry. The load of the wall beside the roadway increases with the development of roof subsidence, and its rate features the cycle of "slow-fast-slow".

CHCT paste filling material is developed based on the raw materials consisting of crushed stone, sand, cement, coal ash, additive and water. The maximum strength of the material can reach up to $7,12,16$, and $28 \mathrm{MPa}$ respectively in 1, 3, 7 and $28 \mathrm{~d}$.

The paste strength and roof load dynamically develop during the mining period. In order to ensure the intactness of the roadside wall, the paste strength should be greater than the roof load at every stage. Otherwise, measures should be taken to alleviate the pressure exerted on the wall. 
The industrial test shows that the roof load should be less than the wall strength at each stage so as to ensure the stability of the wall. The results have been verified by actual effects.

\section{Acknowledgments}

The Project was supported by the National Natural Science Foundation of China (51404251), by the Natural Science Foundation of Jiangsu Province of China (BK20140198), by the Innovative Research Team in University by Ministry of Education of China (IRT_14R55), and by the Priority Academic Program Development of Jiangsu Higher Education Institutions.

\section{References}

Han, C.L., Zhang, N., Li, B.Y., Si, G.Y. and Li, B.G. 2015, 'Pressure relief and structure stability mechanism of hard roof for gob-side entry retaining', Journal of Central South University, vol. 22, no. 11, pp. 4445-4455.

Han, C.L., Zhang, N., Wang, X.Q., Li, B.Y. and Li, Z.B. 2013, 'Bearing behavior of block wall structure in gob-side entry retaining and its application', Journal of Mining and Safety Engineering, vol. 30, no. 5, pp. 673-678.

Han, C.L. 2013, 'Stress Optimization and Structure Stability Control for the Surrounding Rock of Gob-side Entry Retaining', PhD thesis, China University of Mining and Technology, Xuzhou.

Han, C.L., Zhang, N., Yao, Y.H., Zhang, N.C. and Ming, J. 2013, 'Transfer bearing mechanism of thick composite roof in gob-side entry retaining', Rock and Soil Mechanics, vol. 34, no. S1, pp. 318-323.

Hua, X.Z. and Li, Y.F. 2016, 'Mechanics analysis on floor deformation of gob-side entry retaining and prevention and control of floor heave', Journal of China Coal Society, vol. 41, no. 7, pp. 1624-1631.

Kang, H.P., Niu, D.L., Zhang, Z., Lin, J., Li, Z.H. and Fan, M.J. 2010, 'Deformation characteristics of surrounding rock and supporting technology of gob-side entry retaining in deep coal mine', Chinese Journal of Rock Mechanics and Engineering, vol. 29, no. 10, pp. 1977-1987.

Li, X.H., Ju, M.H., Yao, Q.L., Zhou, J. and Chong, Z.H. 2016, 'Numerical Investigation of the Effect of the Location of Critical Rock Block Fracture on Crack Evolution in a Gob-side Filling Wall', Rock Mechanics and Rock Engineering, vol. 49, no. 3, pp. 1041-1058.

Ning, J.G., Ma, P.F., Liu, X.S., Zhou, J. and Liu, W. 2013, 'Supporting mechanism of "yielding-supporting" beside roadway maintained along the goaf under hard rocks'. Journal of Mining and Safety Engineering, vol. 30, no. 3, pp. 369-374.

Sun, X.M., Liu, X., Liang, G.F., Wang, D. and Jiang, Y.L. 2014, 'Key parameters of gob-side entry retaining formed by roof cut and pressure releasing in thin coal seams'. Chinese Journal of Rock Mechanics and Engineering, vol. 33, no. 7, pp. 1449-1456.

Tan, Y.L., Yu, F.H., Ning, J.G. and Zhao, T.B. 2016, 'Adaptability theory of roadside support in gob-side entry retaining and its supporting design', Journal of China Coal Society, vol. 41, no. 2, pp. 376-382.

Tan, Y.L., Yu, F.H., Ning, J.G. and Zhao, T.B. 2015, 'Design and construction of entry retaining wall along a gob side under hard roof stratum'. International Journal of Rock Mechanics and Mining Sciences, vol. 77, pp. 115-121.

Wang, P. and Zhang, Y.H. 2016, 'Performance Improvement for High-water-content Filling Material Beside Gob-side Entry Retaining', Safety in Coal Mines, vol. 47, no. 2, pp. 51-54.

Wang, W.M., Xu, F. and Qin, W.L. 2013, 'Coal Rejects Backfill Support Technology of Gob-side Entry Retaining in High Gassy Mine', Coal Science and Technology, vol. 41, no. 12, pp. 1-3.

Xie, S.R., Xu, L., Zhang, G.C., Gong, S.Y. and Yang, L.G. 2015, 'Subsidence broken of deep gob-side entry retaining surrounding rock structure with large mining height and its control', Rock and Soil Mechanics, vol. 36, no. 2, pp. 569-575.

Ye, G.X., Zhu, Q.J., Li, S. and Yu, Z. 2016, 'Development and application of composite filling body in gob-side entry retaining with 1000 m-plus deep coal mine', Journal of Mining and Safety Engineering, vol. 33, no. 5, pp. 787-794.

Zhang, D.S., Miao, X.X., Feng, G.M. and Song, Z.Q. 2003, 'Stability control of packing body for gob-side entry retaining in fullymechanized coal faces with top-coal caving', Journal of China University of Mining and Technology, vol. 32, no. 3, pp. $232-235$.

Zhang, N., Yuan, L., Han, C.L., Xue, J.H. and Kan, J.G. 2012, 'Stability and deformation of surrounding rock in pillarless gob-side entry retaining', Safety Science, vol. 50, no. 4, pp. 593-599. 